\title{
THE ASSESSMENT OF HEALTH PROTOCOL IMPLEMENTATION IN FOOD AND BEVERAGES BUSINESS DURING COVID-19 PANDEMIC ERA
}

\author{
Lusi Sandra Hutahaean ${ }^{1}$, Muhammad Ilyas ${ }^{1}$, Marsen Isbayuputra ${ }^{1}$, Ray Basrowi ${ }^{1}$, Dewi Soemarko ${ }^{1}$ \\ ${ }^{1}$ Occupational Medicine, Community Health Science, University of Indonesia \\ Faculty of Medicine, University of Indonesia, Salemba Raya 6, Jakarta 10430, Indonesia \\ Correspondence Address: Ray Wagiu Basrowi \\ E-mail: ray.basrowi@gmail.com
}

\begin{abstract}
During the COVID-19 pandemic era, the government has implemented a new strategy of health protocol called Adaptation of New Habits to prevent COVID -19 virus spread. By implementing such protocol, it is expected that health and economic sectors can be handled well. The research aims to discover the implementation of health protocol in Indonesia's food and beverage business, and to analyze factors that support and hamper its implementation. This research was cross-sectional research with direct observation and brief interviews with 16 food and beverage business places. Observations and interviews were guided using a checklist derived from government policies set by the ministry of health and commerce then the data will be analyzed descriptively. This research shows that the implementation health protocol remained far from expectations. Moreover, business activity, management system, and the awareness of employers, employees, as well as consumers, became a critical key in health protocol implementation. Comprehending the dangers of COVID-19 and committing to comply with health protocols are imperatives to succeed in the health protocol implementation.
\end{abstract}

Keywords: Adaptation of New Habits, Health Protocol of COVID-19 Pandemic, evaluating health protocols implementation

\section{INTRODUCTION}

Coronavirus disease 2019 (COVID19) pandemic causes changes of habits and lifestyles. Such changes are attempts to minimize the virus spread and to make life back to normal as before the pandemic era. Responding to those efforts, the government has been actively socializing the Adaptation of New Habits (ANH) to decrease the spread of the COVID-19 virus (Indonesia, 2020). The policy stipulated by several Ministries, such as The Ministry of Health and The Ministry of Commerce. They expected that the wheels of the economy remain spinning without forfeiting health sectors (Ministry of Finance of the Republic of Indonesia, 2020) (Ministry of Health of the Republic of Indonesia, 2020) (Ministry of Trade, 2020).
To date, there is not any evidence stating that the COVID-19 virus can be transmitted through food. The risk of transmitting COVID-19 through food and food packaging is very low as long as the Good Processed Food Production Method is undertaken by all industrial sectors in every food supply chain. However, the implementation of health protocols in preventing transmission of COVID-19 must remain undertook due to the social and physical interactions between individuals in food and beverage business (National Agency of Drug and Food Control, 2020).

Research undertaken by federal researchers in 3,076 (97.9\%) countries in the United States stated that subsequent to the reoperation of restaurants and on-site dining service, regions that open restaurants to eat 
on the premises - indoors or outdoors - had an increase in daily infections about six weeks later, and an increase in the COVID-19 mortality two months later (Guy, Massetti and Sauber-Schatz, 2021). The state of Los Angeles claimed that restaurants have contributed less than $4 \%$ of the COVID-19 outbreak virus in non-residential environments. In Indonesia, eating outside the house certainly reflects the contribution in increasing the spread of the COVID-19 virus. The magnitude of the effect from eating in restaurants or other food businesses emerge from two matters: (1) the movement to release masks during meals and (2) contact among workers, consumers, and workers and consumers due to the limited space and poor air circulation (ABC, 2021) (Guy, Massetti and Sauber-Schatz, 2021).

A policy stipulation constitutes a good initial step, yet it should be followed by further actions to ensure its effectivity and well-implementation throughout Indonesian society. Its workability needs to be reviewed to make it applicable and appropriate in such condition, considering the owners of food and beverage businesses are being forced to survive with declined earnings while this health protocol application raises expenses which includes the provision of PPE, extensive materials, and other supporting equipment that must be adjusted to the type of business activities (Burki, 2020) (Central Bureau of Statistics, 2020). This research aims to discover the implementation of ANH health protocol in the food and beverage business as well as to analyze factors that play as supports and obstacles of the policy implementation.

\section{METHODS}

The study was cross-sectional, through direct observation towards activities and health protocol implementation at food and beverage business places during operational hours and brief interviews both to business owners and employees at one time (Setia, 2016). Data collection was derived during October-November 2020 in Jakarta Capital Special Region, Tangerang, and Medan, the observation was held at hours when most visitors came and the interview was adjusted to the condition of busyness. The population of this study was all food and beverage businesses that remain operated during the pandemic, affordable places of business located in the cities of Jakarta, Tangerang, Depok, Bogor, and Medan. After acquiring their consent, 16 business places were willing to be research subjects. Observations and interviews were guided using a checklist derived from government policies set by the ministry of health and The Ministry of Commerce (Ministry of Health of the Republic of Indonesia, 2020) (Ministry of Trade, 2020) (OSHA, 2020).

The observation was undertaken in 16 food and beverage businesses consisting of Micro, Small, and Medium Enterprises, franchises, and restaurants which divided equally into 4 risk criteria based on risk scale classification for restaurants by the Centers For Disease Control And Prevention (CDC) in The United States of America (CDC, 2020). Low Risk was described as limited food services at a drive-through, delivery, take-out, such as restaurants that provide delivery orders through the online application as well as order by phone. Medium Risk was described as besides providing means such as drive-through, delivery, picking up, and roadside buying, the place/restaurant also provided the dine-in facility with limited capacity compared to the one before a pandemic or offered seats outdoor. The seating capacity was decreased to keep the distance at least 1 meter. High Risk was described as dine-in both indoor and outdoor. The capacity was decreased to keep distance between the tables and visitors. Very High Risk was described as dine-in both indoor 
and outdoor. The capacity was not decreased and the distance between the tables and visitors was less than one meter such as warung Tegal and other traditional restaurants.

The data was analyzed using Risk Rating with formulas (Peters et al., 2019):

\section{Risk Rating $=$ Consequences $\mathrm{x}$ Probability}

Whereas:

Consequences were set as a constant with equal value in each policy since it has equal risk: being exposed to COVID-19 virus. Therefore, the score will be given.

Probability constituted a percentage derived from the number of business places to every risk group that did not implement health protocols as appropriate to the government policy.

Then the data was analyzed by using Health Risk Assessment (HRA) to know risk levels of every category of food and beverage business place (National Research Council, 2003). Then, the derived risk rating was classified based on cross points adjusted to the assessment system, therefore it was found factors that supported and hampered the program implementation. the assessment results from the risk assessment have a range of values from 0 to 400 . To facilitate the grouping, it will be divided into 4 categories: good, fair, poor, and very poor.

This study has passed the ethical review of the Health Research Ethics Committee of the Faculty of Medicine, University of Indonesia - RSUPN. Dr. Cipto Mangunkusumo with number KET-355 / UN2.F1 / ETIK.PPM.00.02 / 2021.

\section{RESULTS}

Based on the results of observation guided using check-list point, 30 policies became the focus of observation in implementing health protocols, whereas the first 20 targets for business owners and the next 10 targets for employees as mentioned in Table 3. The research subjects consist of 16 places of business which are divided into 4 categories of risk rating. Each category consists of 4 places of business.

Table 1. Results of Walk Through Survey Implementation of Health Protocol Policy

\begin{tabular}{|c|c|c|}
\hline $\begin{array}{c}\text { Total } \\
\text { Score Of } \\
\text { Risk } \\
\text { Assessmen } \\
\text { t }\end{array}$ & $\begin{array}{c}\text { Result Of } \\
\text { Observation } \\
\text { Implementatio } \\
\text { n Of Each } \\
\text { Policy }\end{array}$ & $\begin{array}{c}\text { Category } \\
\text { Implementaio } \\
\text { n In Site }\end{array}$ \\
\hline $0-99$ & 0 & Good \\
\hline 100-199 & 7 & Fair \\
\hline 200-299 & 17 & Poor \\
\hline $300-400$ & 8 & Very Poor \\
\hline
\end{tabular}

Based on HRA, by calculating the Risk Rating of each risk group of business place (calculation horizontally to every policy), the result showed that none of the health protocol policies was categorized as well-implemented. The calculation was undertaken for every risk group (calculation vertically to every risk group), whereas those having the smallest score constitute a group of business places that implemented the best health protocols compared to other groups with the bigger total score. 
Table 2. Health Risk Assessment (HRA) results of walkthrough survey at 16 places of food and beverage business

\begin{tabular}{|c|c|c|c|c|c|c|}
\hline \multirow[b]{2}{*}{ Targets } & \multirow[b]{2}{*}{ Policies } & \multicolumn{4}{|c|}{ The score of Risk Rating } & \multirow{2}{*}{$\begin{array}{c}\text { Total Score } \\
\text { Of Risk } \\
\text { Assessment }\end{array}$} \\
\hline & & $\begin{array}{l}\text { Low } \\
\text { Risk }\end{array}$ & $\begin{array}{l}\text { Medium } \\
\text { Risk }\end{array}$ & $\begin{array}{l}\text { High } \\
\text { Risk }\end{array}$ & $\begin{array}{l}\text { Very } \\
\text { High } \\
\text { Risk }\end{array}$ & \\
\hline \multirow[t]{9}{*}{$\begin{array}{l}\text { Business } \\
\text { Owners }\end{array}$} & $\begin{array}{l}\text { Provide facilities for washing } \\
\text { hands using soaps and hand } \\
\text { sanitizer }\end{array}$ & & & & & \\
\hline & Entrance & 0 & 50 & 50 & 100 & 200 \\
\hline & Strategic Places & 50 & 50 & 75 & 75 & 250 \\
\hline & $\begin{array}{l}\text { Require every person who } \\
\text { wants to get in, to wash hands } \\
\text { with soaps water, or use hand } \\
\text { sanitizer. }\end{array}$ & 75 & 25 & 75 & 100 & 275 \\
\hline & $\begin{array}{l}\text { Require employees to wear } \\
\text { masks during working. }\end{array}$ & 25 & 25 & 25 & 75 & 150 \\
\hline & $\begin{array}{l}\text { Prohibit to get in for employees } \\
\text { and visitors who have } \\
\text { symptoms of fever, cough, cold, } \\
\text { sore throat, shortness of breath, } \\
\text { and/or diarrhea or those have } \\
\text { history contacted to persons } \\
\text { exposed to COVID-19. }\end{array}$ & 75 & 75 & 75 & 100 & 325 \\
\hline & $\begin{array}{l}\text { Do checking up body } \\
\text { temperature at the entrance. } \\
\text { When founding employees or } \\
\text { visitors with temperature > } \\
37.3^{\circ} \mathrm{C} \text { ( twice checking with } \\
\text { interval } 5 \text { minutes) they are not } \\
\text { allowed to get in. }\end{array}$ & 100 & 25 & 25 & 100 & 250 \\
\hline & $\begin{array}{l}\text { Require all those touching food } \\
\text { or employees who have direct } \\
\text { contact with food, to wear } \\
\text { masks, gloves, or tongs when } \\
\text { touching fast food, and wear } \\
\text { head covers and apron while } \\
\text { preparing, cooking, and serving } \\
\text { food. Using gloves as adjusted } \\
\text { to the prevailing food safety } \\
\text { standard. }\end{array}$ & 50 & 25 & 25 & 75 & 175 \\
\hline & $\begin{array}{l}\text { Provide aids such as gloves } \\
\text { and/or tongs to minimize direct } \\
\text { contact with fast food during the }\end{array}$ & 75 & 25 & 75 & 75 & 250 \\
\hline
\end{tabular}




\begin{tabular}{|c|c|c|c|c|c|c|}
\hline \multirow{8}{*}{ Targets } & \multirow[b]{2}{*}{ Policies } & \multicolumn{4}{|c|}{ The score of Risk Rating } & \multirow{2}{*}{$\begin{array}{c}\text { Total Score } \\
\text { Of Risk } \\
\text { Assessment }\end{array}$} \\
\hline & & $\begin{array}{l}\text { Low } \\
\text { Risk }\end{array}$ & $\begin{array}{c}\text { Medium } \\
\text { Risk }\end{array}$ & $\begin{array}{l}\text { High } \\
\text { Risk }\end{array}$ & $\begin{array}{l}\text { Very } \\
\text { High } \\
\text { Risk }\end{array}$ & \\
\hline & $\begin{array}{l}\text { process of preparation, cooking, } \\
\text { and serving. }\end{array}$ & & & & & \\
\hline & $\begin{array}{l}\text { Do not provide a buffet. When } \\
\text { providing buffet then } \\
\text { recommended to employ service } \\
\text { officers at the stalls and they } \\
\text { wear masks and gloves. They } \\
\text { serve taking foods for the } \\
\text { visitors and keep distancing at a } \\
\text { minimum of } 1 \text { meter. All } \\
\text { cutleries must be rinsed and } \\
\text { disinfected before re-use. }\end{array}$ & 50 & 25 & 50 & 75 & 200 \\
\hline & $\begin{array}{l}\text { Keep the air quality at } \\
\text { businesses or workplaces by } \\
\text { optimizing air circulation and } \\
\text { sunlight coming in and also } \\
\text { cleaning AC filters. }\end{array}$ & 50 & 50 & 50 & 75 & 225 \\
\hline & $\begin{array}{l}\text { Procure payment through } \\
\text { cashless by providing } \\
\text { disinfection to payment } \\
\text { machine. When having a } \\
\text { transaction with cash use hand } \\
\text { sanitizer after doing it. }\end{array}$ & 50 & 25 & 50 & 75 & 200 \\
\hline & $\begin{array}{l}\text { Make sure that all surroundings } \\
\text { of restaurants are clean and } \\
\text { sanitized, by doing cleanup and } \\
\text { disinfection periodically at least } \\
\text { twice a day (before open and } \\
\text { close) with appropriate cleaner } \\
\text { and disinfectant. }\end{array}$ & 25 & 25 & 25 & 25 & 100 \\
\hline & $\begin{array}{l}\text { Increase frequencies of cleanup } \\
\text { and disinfection (st } 3 \text { times a } \\
\text { day) mainly the surfaces of area } \\
\text { and facilities frequently } \\
\text { touched/passed by people such } \\
\text { as tables and seats in the dining } \\
\text { room, door handles, toilet flush } \\
\text { handles, teller machine, and } \\
\text { others. }\end{array}$ & 75 & 50 & 50 & 100 & 275 \\
\hline
\end{tabular}




\begin{tabular}{|c|c|c|c|c|c|c|}
\hline \multirow{9}{*}{ Targets } & \multirow[b]{2}{*}{ Policies } & \multicolumn{4}{|c|}{ The score of Risk Rating } & \multirow{2}{*}{$\begin{array}{c}\text { Total Score } \\
\text { Of Risk } \\
\text { Assessment } \\
\end{array}$} \\
\hline & & $\begin{array}{l}\text { Low } \\
\text { Risk }\end{array}$ & $\begin{array}{c}\text { Medium } \\
\text { Risk }\end{array}$ & $\begin{array}{l}\text { High } \\
\text { Risk }\end{array}$ & $\begin{array}{l}\text { Very } \\
\text { High } \\
\text { Risk }\end{array}$ & \\
\hline & $\begin{array}{l}\text { Cover cutlery placed on the } \\
\text { dining tables (spoons, forks, } \\
\text { knives wrapped with tissue). }\end{array}$ & 100 & 25 & 50 & 100 & 275 \\
\hline & $\begin{array}{l}\text { Do not use cutlery jointly. The } \\
\text { frequently touched cutlery on } \\
\text { the dining table should be } \\
\text { changed into a one-used sachet } \\
\text { or given to the visitors if } \\
\text { requested. }\end{array}$ & 0 & 25 & 50 & 100 & 175 \\
\hline & $\begin{array}{l}\text { Apply to keep a distance with } \\
\text { various techniques such as: }\end{array}$ & & & & & \\
\hline & $\begin{array}{l}\text { a. Maintaining a distance of at } \\
\text { least } 1 \text { meter while queuing up } \\
\text { to enter restaurants and similar } \\
\text { ones, ordering and paying at the } \\
\text { cashier by providing marks on } \\
\text { the floor. When possible, } \\
\text { providing borders between } \\
\text { visitors and cashiers such as } \\
\text { control partition or glass. }\end{array}$ & 25 & 25 & 50 & 75 & 175 \\
\hline & $\begin{array}{l}\text { b. Maintaining distance between } \\
\text { seats at a minimum of } 1 \text { meter } \\
\text { and not face to face, or installing } \\
\text { partitions (glass, mica, or } \\
\text { plastic) between guests on } \\
\text { dining tables. }\end{array}$ & 100 & 0 & 75 & 75 & 250 \\
\hline & $\begin{array}{l}\text { Increase service for food and } \\
\text { beverage orders through online } \\
\text { or delivery service or drive-thru, } \\
\text { and others. }\end{array}$ & 50 & 50 & 75 & 75 & 250 \\
\hline & $\begin{array}{l}\text { Apply to maintain circulation } \\
\text { and limitation for visiting time } \\
\text { and number of visitors } \\
\text { maximum } 40 \% \text { of visits at } \\
\text { normal condition by } \\
\text { implementing strict control at } \\
\text { the entrance and exit in such a } \\
\text { way so that not to occur crowd } \\
\text { by health protocols. }\end{array}$ & 75 & 25 & 50 & 75 & 225 \\
\hline
\end{tabular}




\begin{tabular}{|c|c|c|c|c|c|c|}
\hline \multirow{5}{*}{ Targets } & \multirow{2}{*}{ Policies } & \multicolumn{4}{|c|}{ The score of Risk Rating } & \multirow{2}{*}{$\begin{array}{c}\text { Total Score } \\
\text { Of Risk } \\
\text { Assessment }\end{array}$} \\
\hline & & $\begin{array}{l}\text { Low } \\
\text { Risk }\end{array}$ & $\begin{array}{l}\text { Medium } \\
\text { Risk }\end{array}$ & $\begin{array}{l}\text { High } \\
\text { Risk }\end{array}$ & $\begin{array}{l}\text { Very } \\
\text { High } \\
\text { Risk }\end{array}$ & \\
\hline & $\begin{array}{l}\text { Make sure that all officers, } \\
\text { managers, and waitresses of } \\
\text { restaurants are negative } \\
\text { COVID-19 based on results of } \\
\text { PCR/Rapid Test which were } \\
\text { conducted by the restaurant } \\
\text { owner, or local health unit, and } \\
\text { wear masks, face shields, and } \\
\text { gloves while having activities. }\end{array}$ & 100 & 75 & 100 & 100 & 375 \\
\hline & $\begin{array}{l}\text { Before restaurants open, } \\
\text { conduct early screening to make } \\
\text { sure that the body temperatures } \\
\text { of all officers, managers, and } \\
\text { waitresses of the restaurants are } \\
\text { below } 37.3^{\circ} \mathrm{C} \text { (adjusted to WHO } \\
\text { regulation). }\end{array}$ & 75 & 50 & 50 & 100 & 275 \\
\hline & Sell clean and healthy food. & 25 & 0 & 25 & 50 & 100 \\
\hline \multirow[t]{6}{*}{$\begin{array}{l}\text { Worker } \\
\text { s }\end{array}$} & $\begin{array}{l}\text { Make sure themselves in } \\
\text { healthy condition before leaving } \\
\text { their house. If having } \\
\text { symptoms such as fever, cough, } \\
\text { cold, sore throat, and/or } \\
\text { shortness of breath they must } \\
\text { stay at home and check up to } \\
\text { health service if the symptoms } \\
\text { keep running, and report to } \\
\text { leaders of the workplace. }\end{array}$ & 75 & 75 & 75 & 100 & 325 \\
\hline & $\begin{array}{l}\text { Wear masks during the journey } \\
\text { and while in the workplace. }\end{array}$ & 50 & 50 & 50 & 50 & 200 \\
\hline & $\begin{array}{l}\text { Avoid touching face, eyes, } \\
\text { nose, and mouth. }\end{array}$ & 50 & 50 & 50 & 50 & 200 \\
\hline & $\begin{array}{l}\text { Care to keep distance at a } \\
\text { minimum of } 1 \text { meter with other } \\
\text { people. }\end{array}$ & 50 & 25 & 50 & 75 & 200 \\
\hline & $\begin{array}{l}\text { Wear specific clothes during } \\
\text { work. }\end{array}$ & 0 & 0 & 0 & 100 & 100 \\
\hline & $\begin{array}{l}\text { Avoid using personal } \\
\text { belongings jointly such as } \\
\text { equipment for doing shalat, } \\
\text { cutlery, and others. }\end{array}$ & 75 & 75 & 75 & 75 & 300 \\
\hline
\end{tabular}




\begin{tabular}{|c|c|c|c|c|c|c|}
\hline \multirow{6}{*}{ Targets } & \multirow[b]{2}{*}{ Policies } & \multicolumn{4}{|c|}{ The score of Risk Rating } & \multirow{2}{*}{$\begin{array}{c}\text { Total Score } \\
\text { Of Risk } \\
\text { Assessment }\end{array}$} \\
\hline & & $\begin{array}{l}\text { Low } \\
\text { Risk }\end{array}$ & $\begin{array}{c}\text { Medium } \\
\text { Risk }\end{array}$ & $\begin{array}{l}\text { High } \\
\text { Risk }\end{array}$ & $\begin{array}{l}\text { Very } \\
\text { High } \\
\text { Risk }\end{array}$ & \\
\hline & $\begin{array}{l}\text { Immediately take a bath and } \\
\text { change clothes before having } \\
\text { contact with family members at } \\
\text { home. }\end{array}$ & 75 & 75 & 75 & 75 & 300 \\
\hline & $\begin{array}{l}\text { If needed, clean mobile phone, } \\
\text { glasses, bag, and other stuff } \\
\text { with disinfectant liquid. }\end{array}$ & 75 & 75 & 75 & 75 & 300 \\
\hline & $\begin{array}{l}\text { When arriving home, } \\
\text { immediately take a bath and } \\
\text { change clothes before having } \\
\text { contact with family members at } \\
\text { home. Clean mobile phone, } \\
\text { glasses, bag, and other stuff with } \\
\text { disinfectant liquid. }\end{array}$ & 75 & 75 & 75 & 75 & 300 \\
\hline & $\begin{array}{l}\text { Increase the body stamina by } \\
\text { applying Clean and Healthy } \\
\text { Lifestyle (PHBS) such as } \\
\text { consuming balanced nutrition, } \\
\text { physical activities minimum of } \\
30 \text { minutes a day and have } \\
\text { enough rest with sleep } \\
\text { minimum of } 7 \text { hours, and avoid } \\
\text { factors of disease risks. }\end{array}$ & 75 & 75 & 75 & 75 & 300 \\
\hline & & $\begin{array}{c}\text { LO } \\
\text { W } \\
\text { RIS } \\
\text { K } \\
\text { III } \\
1.85 \\
0\end{array}$ & $\begin{array}{c}\text { MEDIU } \\
\text { M RISK } \\
\text { I } \\
1.325\end{array}$ & $\begin{array}{c}\text { HIGH } \\
\text { RISK } \\
\text { II } \\
1.775\end{array}$ & $\begin{array}{c}\text { VER } \\
\text { Y } \\
\text { HIGH } \\
\text { RISK } \\
\text { IV } \\
2.550\end{array}$ & \\
\hline
\end{tabular}

\section{DISCUSSION}

Based on the Table 1, it can be concluded that generally there was not any health protocol policy that was wellimplemented by food business places in Indonesia. However, there are some policies that have been fairly implemented due to previously good socialization and had been being implemented when the pandemic occurred. Policies that categorized as poorly implemented were commonly dealed with new habits or protocols which were newly socialized during the COVID-19 pandemic. In short, it was less socialized and required awareness of the employers, workers, and 
consumers as well (Ministry of Health of the Republic of Indonesia, 2020) (OSHA, 2020). Policies that categorized as very poor generally had several difficulties in the implementation, such as constituted a binding protocol and had to be implemented strictly and required high understanding and commitment. Any matters happening outside the workplaces and impossible to be directly monitored by the business owner (Food Standard Agency, 2020). They required an amount of financial support thus strong willingness and high commitment from the business owner were strongly advised.

Based on the result in Table 2, it showed that there was a significant incompatibility between the expected results from risk assessment of business places based on types of business activities ( delivery order, dine-in or take away) and the observation results of health protocol implementation in line with the policy stipulated by the government (Agency, 2020). Based on risk grouping from CDC, the business places which only served delivery orders had lower risks than the other risk groups, however, the business places with low risk constituted the second-worst business place that implemented health protocols, therefore they exactly riskier than the business places which provided dine-in system (CDC, 2020)(Han et al., 2021). It occurred since the assessed factors were not only comprising aspects of business types and physical distancing but also the awareness of business owners and workers. This result brought awareness that prevention of virus spread at food and beverages business, the preventive actions should not only rely on types of business activities and physical distancing but also include other factors such as wearing properly Personal Protective Equipment (PPE), habits of washing hands and keeping cleanliness, and strong commitment from the business owner and workers (WHO, 2020) (Anelich et al., 2020).

From the research, it can be concluded that food and beverage business places in Indonesia are still very low in implementing health protocols. The low awareness and understanding of COVID-19 danger influence the low commitment of business owners, workers, and consumers in implementing health protocols (Bazaid et al., 2020). The stipulation of a health protocol policy for every industrial activity is a good initial step to prevent transmission of the COVID-19 virus, yet it should be continued with farther steps including socialization, implementation, supervision, and evaluation of this policy (Zhang et al., 2021). Some policies remain ineffective since they need huge financial supports, such as obligating the business owners to ensure all workers in condition negative COVID-19 based on evidence of test result PCR/Rapid Test required huge amount of money since it is mandatory periodically (Ministry of Health of the Republic of Indonesia, 2020). On the other hand, at the same time, the business owners were struggling to survive their business facing uncertain economic conditions (Indonesia, 2021).

Based on the result of the research, it is necessary to establish the effective health protocols and adjusted them to each site condition and business scale, such as Micro, Small, Medium Enterprises. They possses limited resources yet they contribute significantly on Indonesia's economy (Ministry of National Development Planning of the Republic of Indonesia, 2017).

\section{CONCLUSION}

Based on the research, it was found that the distribution of the risk scale based on the $\mathrm{CDC}$ was remain inappropriate $(\mathrm{CDC}$, 2020). In Indonesia, where food providers that serve delivery services are mostly a 
micro-business scale, they have a greater risk of transmitting the covid-19 virus compared to other business places that serve dine-in. This is in contrary to the division set by the CDC which stated that restaurants that serve dine-in become restaurants that have a high risk of transmitting the COVID-19 virus. Analyzing the existing data, several factors that led to this can be explained. The main factor was that food service establishments that only serve delivery services are generally micro-scale businesses that have many limited resources, such as a small business area which makes it difficult to maintain physical distance between workers and consumers as well as poor air circulation. The minimal provision of PPE was also a factor that increases the spread of the COVID-19 virus in the work environment.

The poor application of health protocols in food supply businesses was generally caused by a lack of awareness, understanding, and commitment of business owners and workers in implementing proper and correct health protocols on an ongoing basis.

\section{REFERENCES}

ABC (2021) Restaurants linked to less than $4 \%$ of COVID-19 outbreaks in businesses despite outdoor dining suspension - ABC7 Los Angeles.

Agency, F. S. (2020) Adapting restaurants and food delivery during COVID-19| Food Standards Agency.

Anelich, L. E. C. M. et al. (2020) 'SARSCoV-2 and Risk to Food Safety', Frontiers in Nutrition. Frontiers Media S.A. doi: 10.3389/fnut.2020.580551.

Bazaid, A. S. et al. (2020) 'Knowledge and practice of personal protective measures during the COVID-19 pandemic: A cross-sectional study in Saudi Arabia', PLOS ONE. Edited by
R. Kumar, 15(12), p. e0243695. doi: 10.1371/journal.pone.0243695.

Burki, T. (2020) 'Global shortage of personal protective equipment', The Lancet. Infectious diseases, 20(7), pp. 785$786 . \quad$ doi: 10.1016/S14733099(20)30501-6.

Central Bureau of Statistics (2020) Considerations for Restaurants and Bars | COVID-19 | CDC, Centre for Disease Control and Prevention.

Central Bureau of Statistics (2020) analysis of the results of a survey of the impact of COVID-19 on business actors.

Food Standard Agency (2020) Guidance for food businesses on coronavirus (COVID-19).

Guy, G. P., Massetti, G. M. and SauberSchatz, E. (2021) 'Mask Mandates, On-Premises Dining, and COVID19', JAMA - Journal of the American Medical Association. American Medical Association, pp. 350-354. doi: 10.1001/jama.2021.5455.

Han, S. et al. (2021) 'COVID-19 pandemic crisis and food safety: Implications and inactivation strategies.', Trends in food science \& technology, 109, pp. 25-36. doi: 10.1016/j.tifs.2021.01.004.

Indonesia, C. (2021) Pilih Tutup Gerai, Restoran Rumahkan 400 Ribu Karyawan, 2021.

Indonesia, P. (2020) The President's Five Directives regarding the Application of New Habit Adaptations.

Ministry of Finance of the Republic of Indonesia (2020) Government Strives to Restore Balanced Economic and Health Sectors Amid the Covid-19 Pandemic, Ministry of Finance of the Republic of Indonesia.

Ministry of Health of the Republic of Indonesia (2020) Decree of the Minister of Health of the Republic of Indonesia Number HK.01.07 / 
MENKES / 382/2020 concerning Health Protocols for Communities in Public Places and Facilities in the Context of Prevention and Control of Corona Virus Disease 2019 (COVID19).

Ministry of National Development Planning of the Republic of Indonesia (2017).

Ministry of Trade (2020) 'Circular of the Minister of Trade Number 12 of 2020 '.

National Agency of Drug and Food Control (2020) Guidelines for the production and distribution of processed food during the COVID-19 health emergency status in Indonesia.

National Research Council (2003) 'Risk assessment: evaluating risks to human health and safety', in Occupational Health and Safety in the Care and Use of Nonhuman Primates. National Academies Press (US), pp. 68-83.

OSHA (2020) COVID-19 Guidance for Restaurants \& Beverage Vendors Offering Takeout or Curbside Pickup.

Peters, R. et al. (2019) 'A quantitative public health risk assessment tool for planning for at-risk populations', American Journal of Public Health, 109(Suppl 4), pp. S286-S289. doi: 10.2105/AJPH.2019.305181.

Setia, M. S. (2016) 'Methodology series module 3: Cross-sectional studies', Indian Journal of Dermatology, 61(3), pp. 261-264. doi: 10.4103/0019-5154.182410.

WHO (2020) 'Rational use of personal protective equipment for coronavirus disease (COVID-19) and consideration if availability is very limited', World Health Organization, 6 April(Panduan Sementara), pp. 131.

Zhang, W. et al. (2021) 'Food Safety in PostCOVID-19 Pandemic: Challenges and Countermeasures', Biosensors. NLM (Medline). doi: 10.3390/bios11030071. 